International Journal of Agriculture and Environmental Research

ISSN: 2455-6939

Volume: 06, Issue: 03 "May-June 2020"

\title{
IRON BASED IMMOBILIZATION FOR METAL CONTAMINATED SOILS
}

\author{
Abioye O. Fayiga \\ Chemistry Program, School of Natural Sciences and Mathematics, \\ Stockton University, Galloway, NJ \\ DOI: 10.46609/IJAER.2020.v06i03.004 URL: https://doi.org/10.46609/IJAER.2020.v06i03.004
}

\begin{abstract}
Remediation of contaminated soils is an important task which aims to reduce the impact of toxic metalloids such as $\mathrm{Cd}, \mathrm{Cu}$ and $\mathrm{As}$ on public health. In-situ immobilization via the addition of soil amendments such as iron-based materials reduces the mobility and transport of these toxic metalloids in the environment. A wide range of iron-based materials have been used for metal immobilization in contaminated soils including iron oxides, zerovalent iron, nano-zerovalent iron (nZVI), iron salts, green synthesized iron oxide nanoparticle (GION) or phytogenic iron oxides nanoparticles (PION), Fe-Al layered double hydroxide and CMC (carboxymethylcellulose) based iron. The reactivity and surface area of zerovalent iron is increased at the nanoscale when utilized as nZVI thereby increasing its effectiveness as demonstrated by previous studies. The efficiency of nZVI in remediation of contaminated soils is limited by the strong tendency of its particles to agglomerate. In order to overcome this limitation and facilitate the delivery and mobility of nZVI in soils, nZVI is immobilized onto a carrier such as resin, potato starch, zeolite, or mesoporous silica or by increasing colloidal stability with the addition of other soil amendments. Even though, there is $\mathrm{g}$ rowing concern over the environmental impact of nanoparticles, the use of plant extracts to synthesize iron nanoparticles is environmentally friendly and economical.
\end{abstract}

Keywords: Remediation; iron; cadmium; arsenic; copper

\section{INTRODUCTION}

Anthropogenic activities such as fertilization, waste disposal, industrialization and mining have led to elevated concentrations of toxic metals such as arsenic (As), chromium $(\mathrm{Cr})$, copper $(\mathrm{Cu})$ and cadmium $(\mathrm{Cd})$ in the environment. There are thousands of contaminated sites in the USA classified "Superfund sites" which exist due to hazardous waste from manufacturing facilities, processing plants, landfills and mining sites (EPA, 2018). "A Superfund site is any land in the 
International Journal of Agriculture and Environmental Research

ISSN: 2455-6939

Volume: 06, Issue: 03 "May-June 2020"

United States that has been contaminated by hazardous waste and identified by the EPA as a candidate for cleanup because it poses a risk to human health and/or the environment and are placed on the National Priorities List (NPL)" (NIH, 2018). Most of the Superfund sites are contaminated with heavy metals with about 306 sites contaminated with chromium, 235 with As and 224 with Cd (EPA, 1996; Nejad et al., 2018). The type of metal contamination is dependent on the type of industrial operation performed at each site (EPA, 1996).

Arsenic exists mostly as the inorganic forms such as arsenite (As III) and arsenate (As V) with arsenite being the most toxic inorganic form of arsenic in the soil (Peters et al., 1996). The US EPA lowered its limit for As in drinking water from 50 to $10 \mathrm{ppb}$ while the European Union (EU) lowered it from 10 to $5 \mathrm{ppb}$ to protect public health from the lethal effects of As (Giacomino et al., 2010). Chromium exists mostly as the Cr (III) and Cr (IV) forms with Cr (III) being the most stable and most predominant in the soil (Namiesnick and Rabajczyk, 2012). Cr (VI) is the most toxic to biological systems in the soils with strong oxidizing properties (Namiesnick and Rabajczyk, 2012). Cr (VI) is more mobile than Cr (III) in the soil especially in the presence of organic matter which acts a reducing agent and favors the retention of $\mathrm{Cr}$ (III) (Galdames et al., 2017). Cd which exists as the +2 ion is one of the most mobile and potentially bioavailable soil elements (Markovic et al., 2019) while $\mathrm{Cu}$ exists as the +1 or +2 ion in the soil solution. The mobilization of $\mathrm{Cd}$ occurs mainly in oxic, acidic conditions while its sorption is enhanced by the presence of high amounts of hydrous oxides, clay minerals, and organic matter (Kubier et al., 2019).

These three metals, As, $\mathrm{Cr}$ and Cd classified as carcinogens are a threat to public health and their release into the environment must be regulated and contained (National Toxicology Program, 2000; Guan et al., 2019; Lin et al., 2019). The mobility of metals in soils have been drastically limited by the addition of readily available and economical amendments such as industrial wastes, iron rich materials and mineral based amendments (Li et al., 2019). It is widely known that iron-rich compounds are effective in immobilizing heavy metals in contaminated soils without risk of secondary contamination (Nejad et al., 2018).

A wide range of iron-based materials have been used for metal immobilization in contaminated soils including iron oxides, zerovalent iron, nano-zerovalent iron (nZVI), supported NVI, iron sulfide, green synthesized iron oxide nanoparticle (GION) or phytogenic iron oxides, Fe-Al layered double hydroxide and CMC (carboxymethylcellulose) based iron (Zhang et al., 2014; Frick et al., 2019; Mitzia et al., 2020; Fresno et al., 2016; Su et al., 2019; He et al., 2018). Iron oxides are generally used in contaminated sites because they are regarded as scavengers of trace metals in soils due to their high reactivity and large surface area (Zhang et al., 2014; Nejad et al., 2018). 
International Journal of Agriculture and Environmental Research

ISSN: 2455-6939

Volume: 06, Issue: 03 "May-June 2020"

The reactivity and surface area of zerovalent iron is increased at the nanoscale when utilized as nZVI thereby increasing its effectiveness as demonstrated by previous studies (Stefaniuk et al., 2016; Wang et al., 2014). However, there may be a need to support nZVI with materials such as biochar, activated carbon, silica as a sorbent in the soil to reduce agglomeration of nZVI (Trakal et al., 2019; Dong et al., 2017). The addition of carboxymethyl cellulose (CMC), a surfactant can also eliminate the inhibition to reactivity of nZVI and can accelerate contaminant removal (Dong and Lo, 2013; Hou et al., 2019). Iron oxide nanoparticles may also be synthesized using plant extracts and advantages of these plant based nZVI are their simplicity of preparation, environmental friendliness and cost effectiveness (Lin et al., 2018). These "green synthesized iron oxide nanoparticles (GION) are also richer in carbon-oxygen functional groups, which provide far more active adsorption sites for both anions and cations than traditionally prepared nanoparticles" (Su et al., 2019). This paper is an overview of research work conducted on ironbased immobilization of metal(loid)s in contaminated soils.

\section{METAL(LOID) CONTAMINATED SOILS}

Globally, As contaminated soils exist due to human activities such as mining, industrial and agricultural activities (Rahman et al., 2019). Arsenic contamination is widespread globally due to the irrigation of agricultural soil with arsenic contaminated groundwater (Garcia-Manyes et al., 2002). Historically, As has been used in a variety of agricultural chemicals such as wood preservative, insecticides, herbicides, algaecides, and growth stimulants (Fillol et al., 2010). The extensive use of the wood preservative chemical known as chromated copper arsenate (CCA), made up of a mixture of $\mathrm{Cr}$ and $\mathrm{Cu}$ salts $\left(\mathrm{CrO}_{3}\right.$ and $\left.\mathrm{CuO}\right)$ and arsenic acid $\left(\mathrm{H}_{3} \mathrm{AsO}_{4}\right)$ since the 1940s has led to sites contaminated with $\mathrm{Cr}, \mathrm{Cu}$ and As (Frick et al., 2019).

In the early 1900s, excessive application of lead arsenate pesticides in apple orchards led to the accumulation of arsenic and lead in the soil (Newton et al., 2006). The use of As containing pesticides at cattle dip vats have also led to elevated As levels in the soil, for example, As concentrations up to $14,000 \mathrm{mg} \mathrm{kg}^{-1}$ have been reported in New South Wales in eastern Australia in a region where the investigation level is $20 \mathrm{mg} \mathrm{kg}^{-1}$ (Rahman et al., 2019). Arsenic contaminated soils have also been reported in golf courses where arsenic containing herbicides were used (Cai et al., 2002). Naturally, As also exists in the soil from the weathering of parent materials in the soil (Giacomino et al., 2010) because it occurs naturally in many kinds of rock, especially ores that contain copper, lead, iron, nickel, and other metals (Fillol et al., 2010). Arsenic is present in natural environments as minerals such as realgar $\left(\mathrm{As}_{4} \mathrm{~S}_{4}\right)$, orpiment $\left(\mathrm{As}_{2} \mathrm{~S}_{3}\right)$, arsenopyrite (FeAsS), arsenolite $\left(\mathrm{As}_{2} \mathrm{O}_{3}\right)$, and scorodite $\left(\mathrm{FeAsO}_{4} \cdot 2 \mathrm{H}_{2} \mathrm{O}\right)$ (Kim et al., 2014).

Chemical processes that determine the mobility, bioavailability and toxicity of As include sorption processes in the soil (Rahman et al., 2019). Processes such as sorption/desorption, 
precipitation, redox reactions may occur on mineral surfaces which may influence the solid-state speciation of As in the soil (Kim and Batchelor, 2009). Arsenate is often present in oxic conditions while arsenite is often found in flooded conditions where reducing conditions are dominant (Newton et al., 2006). Arsenate is often sorbed into organic matter, clays, and iron and manganese oxides and oxyhydroxides (Newton et al., 2006). It has been reported that $\mathrm{Fe}$ and $\mathrm{Al}$ oxy-hydroxides have a higher affinity for As than clays which have more negatively charged surfaces resulting in low As adsorption capacity of clays (Rahman et al., 2019).

Rahman et al. (2019) explained that results of previous studies utilizing X-ray adsorption fine structure spectroscopy and Fourier transform infrared spectroscopy suggest that both arsenate and arsenite form mono- or bidentate inner sphere surface complexes with iron-oxyhydroxides via a ligand exchange mechanism. Iron minerals such as hydrous ferric oxide, goethite, hematite and pyrite are some of the primary minerals controlling arsenic mobility in the soil and are important sinks for As (Kim et al., 2014).

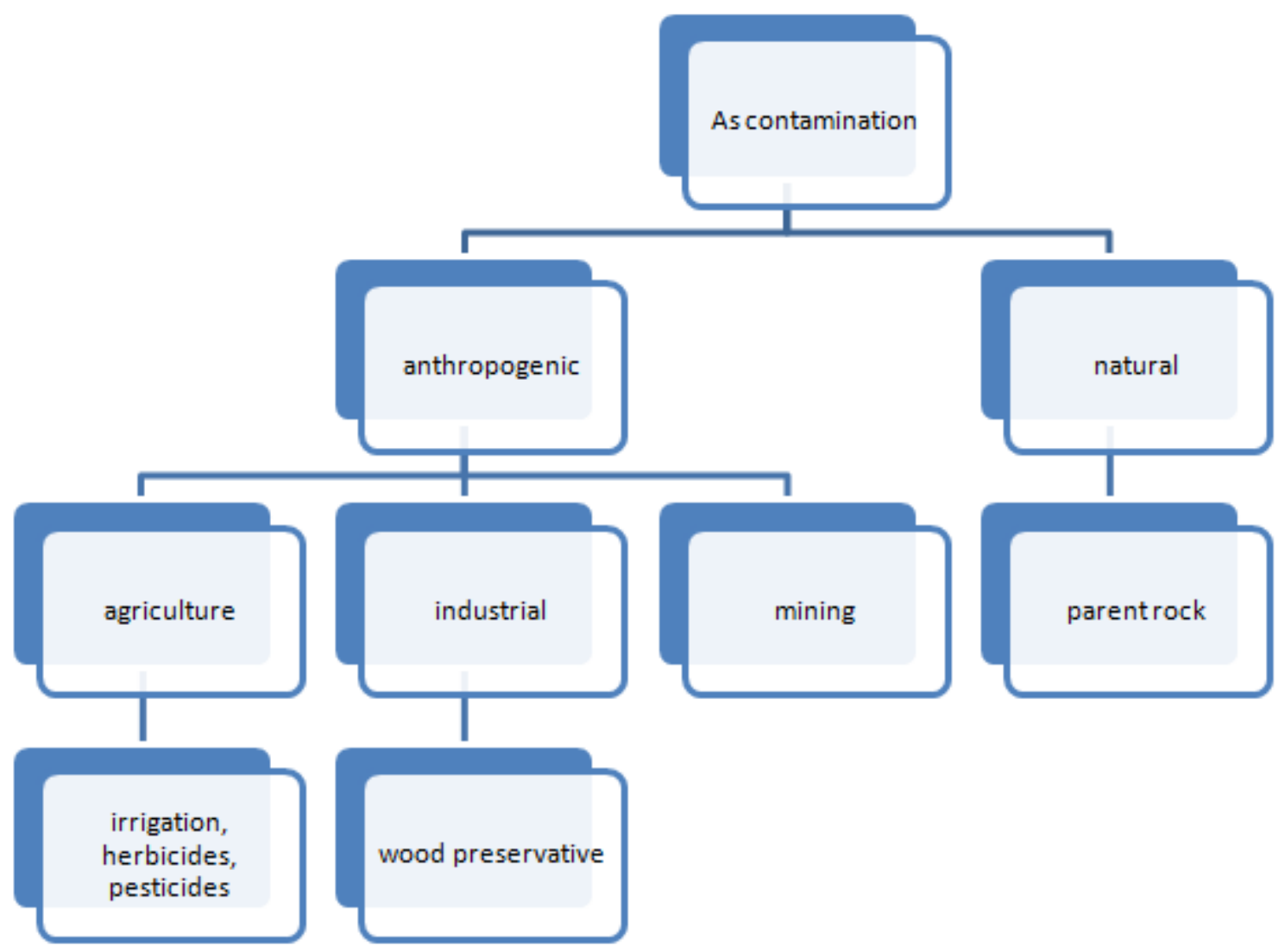

Fig 1: Sources of As contamination 
Copper contamination of soils is associated with smelting, metallurgy, mining and application of biocides (Garrido et al., 2012; Palanivel et al., 2020). The soils surrounding a smelter are not only contaminated with heavy metals such as copper, they are also acidic. They contain up to $680 \mathrm{mg} \mathrm{Cu} / \mathrm{kg}$ soil (Ginocchio, 2000; Ginocchio et al., 2004) with $\mathrm{Cu}$ present as chalcocyanite $\left(\mathrm{CuSO}_{4}\right)$, a highly soluble compound in smelter dust (Neaman et al., 2009). Addition of smelter dust to soils results in their acidification because of formation of sulfuric acid which gives it an extremely acid pH (around 2-3) in solution (Ginocchio et al., 2006). Soil acidification could eventually cause considerably increase in $\mathrm{Cu}$ dissolution in contaminated soils (Sauvé et al., 2000).

Copper contamination is often reported in agricultural soils because of the use of fertilizers and pesticides to improve crop production (Gonzaga et al., 2020). It has been reported that copperbased fungicides are the major source of $\mathrm{Cu}$ contamination in many organic-based farms and vineyards (Meier et al., 2017; Andreazza et al., 2010). In Brazil, soils used for the cultivation of grapes generally have a long history of copper $(\mathrm{Cu})$ based fungicide applications which leads to an accumulation of $\mathrm{Cu}$ at levels that can cause toxicity in plants that co-inhabit the vineyards (Girotto et al., 2016). The use of copper containing dietary supplements in pig farming also leads to copper contamination of soils when pig manure is applied to soils (Cornu et al., 2017).

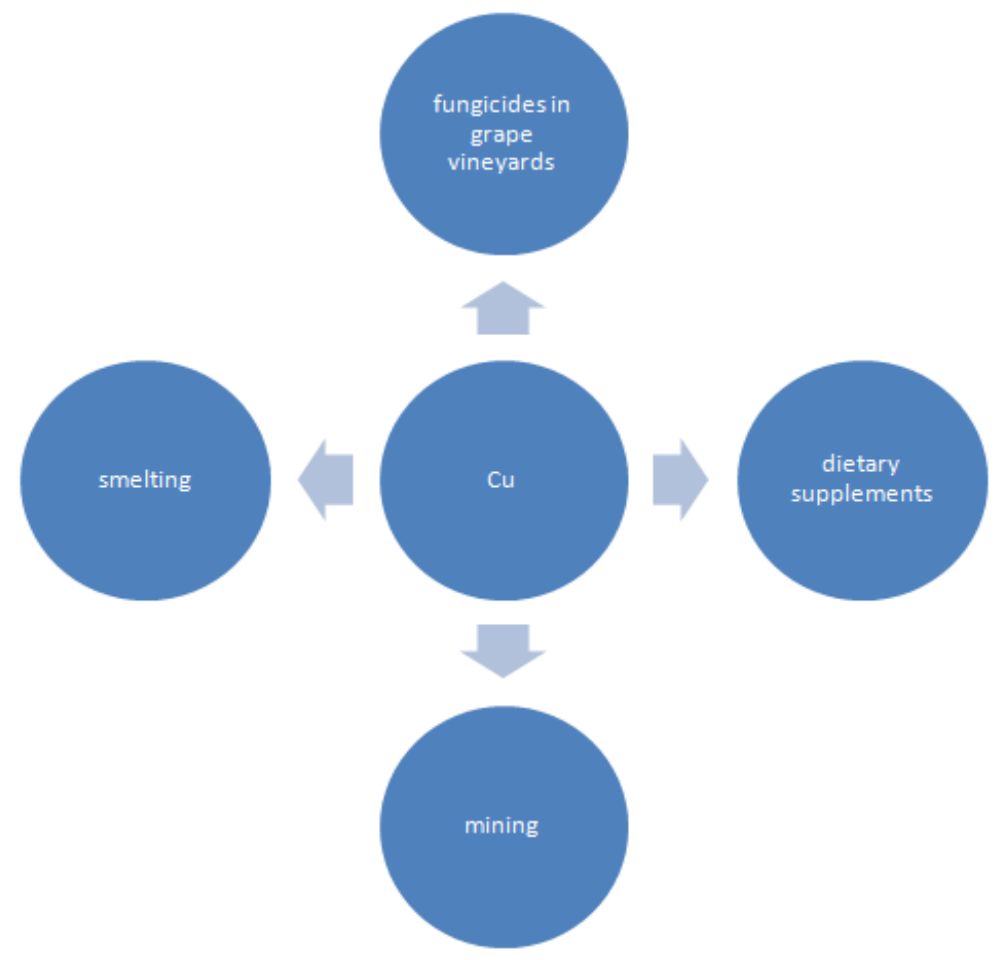

Fig. 2: Sources of Copper contamination in the soil 
In uncontaminated soils, $\mathrm{Cu}$ is naturally found in trace amounts in soil at concentrations ranging from 13 to $24 \mathrm{mg} \mathrm{kg}^{-1}$ (Kabata-Pendias 2001). The highest soil $\mathrm{Cu}$ concentrations are found in the topsoil $(0-30 \mathrm{~cm})$ of copper-mined tailing areas (Shutcha et al. 2015; Cornu et al., 2017) which contain copper in several thousand $\mathrm{mg} \mathrm{kg}^{-1}$ of soil and timber treatment sites. Copper is one of the components of the wood preservative, chromated copper arsenate (CCA), which is one of the common sources of copper contamination in the soil (Frick et al., 2019). Copper concentrations in a copper sulfide mine in Italy ranged from $160-13347 \mathrm{mg} \mathrm{kg}^{-1}$ in waste rock disposal and surrounding soils (Marescotti et al., 2008, 2010, 2013). This high concentration was attributed to the presence of $\mathrm{Cu}$-bearing pyrite, chalchopyrite, $\mathrm{Fe}$-oxides and $\mathrm{Fe}$-oxyhydroxides formed as a consequence of sulfide oxidation processes (Zotti et al., 2014). The main processes governing the mobility of $\mathrm{Cu}$ are the adsorption and desorption of $\mathrm{Cu}$ on these minerals in the soil (Hooda et al., 2010). The mobility of $\mathrm{Cu}$ is high in these sulfidic waste rock dumps which are characterized by low $\mathrm{pH}$, low clay mineral and organic matter content with high permeability (Kabata-Pendias and Mukherjee, 2007).

Even though $\mathrm{Cd}$ is a trace element whose total concentrations in agricultural soil ranges between 0.4 and $0.5 \mathrm{mg} \mathrm{kg}^{-1}$ (Bjelkova et al., 2011), it's one of the most mobile and potentially bioavailable toxic elements in the soil environment (Khan et al., 2017). Heavy application of organic fertilizers on a long-term basis, industrial sewage irrigation and atmospheric $\mathrm{Cd}$ deposition from coal combustion from nearby industries has led to $\mathrm{Cd}$ accumulation and contamination in the soil in greenhouse vegetable production (Zhang et al., 2017; Yang et al., 2020).

Another source of $\mathrm{Cd}$ in agricultural soils are phosphatic fertilizers (Wu et al., 2016) and wastewater irrigation (Sun et al., 2012). Cd contamination can also occur as a result of mining and smelting of metalliferous ores (Cui et al., 2016). In Thailand, abandoned Zn mines are facing issues with $\mathrm{Cd}$ contaminated soils because $\mathrm{Cd}$ ores occur as minor components of $\mathrm{Zn}$ deposits (Inkham et al., 2019). 


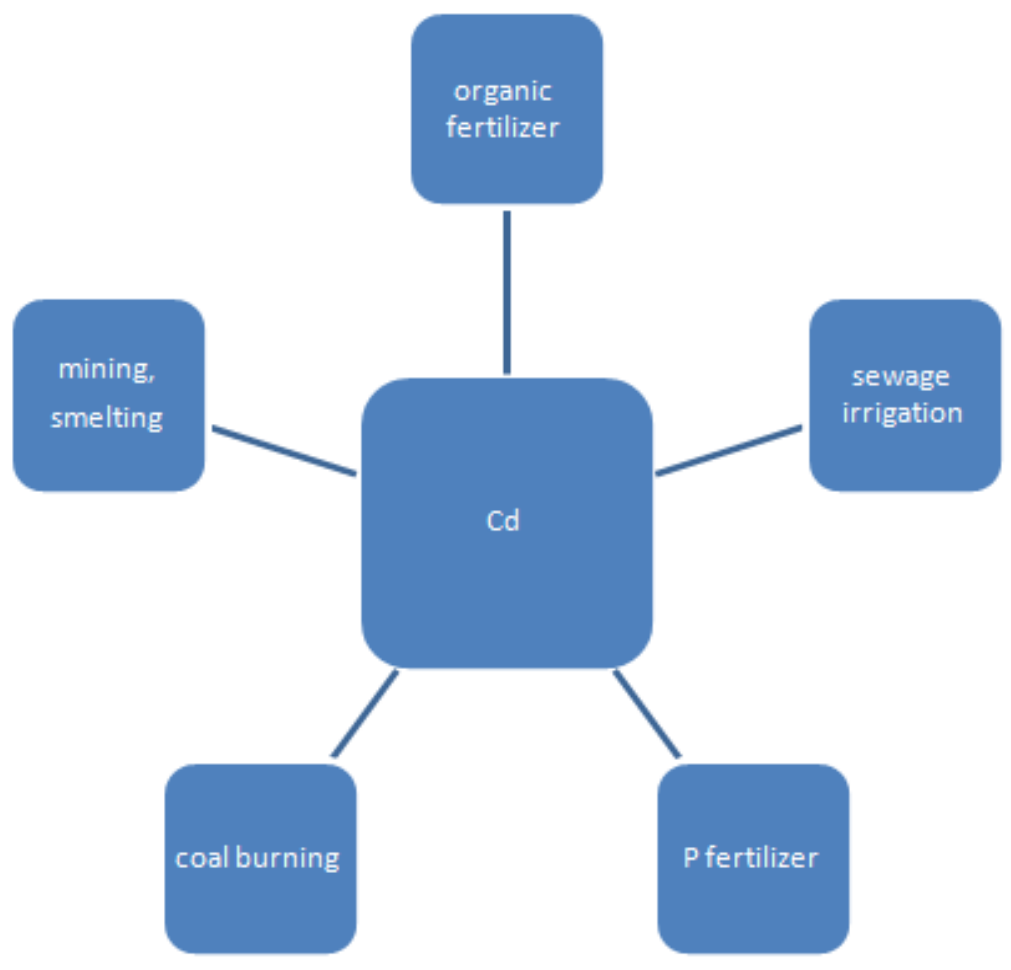

Fig 3: Cd sources in the environment

Cd contamination in the paddy soil of a village in Thailand ranged from 0.1 to $284 \mathrm{mg} \mathrm{kg}^{-1}$ which was much higher than the $\mathrm{Cd}$ content limit of $3 \mathrm{mg} \mathrm{kg}^{-1}$ for agricultural lands in Thailand (Simmons et al., 2005). Other sources of Cd pollution in soils are domestic and sewage sludge including pulp and paper mill waste, printing industry, cement production, wear of automobile tires, lubricants and metallurgical activities (Kabata-Pendias and Mukherjee, 2007; Borah et al., 2018).

$\mathrm{Cr}$ is released into the environment through human activities such as chromate production, electroplating and leather tanning (Su et al., 2016). Other sources of $\mathrm{Cr}$ contamination are wood preservation, uncontrolled treatment of Chromite ore processing residue and $\mathrm{Cr}$-containing wastewater from chromium producing or consuming industries and alloy production (Saha and Orvig, 2010). Illegal discharge of illegal wastes and uncontrolled disposal has led to chromium contamination of groundwater ( $\mathrm{Su}$ et al., 2016). There is extensive chromium contamination in China due to development of industrialization in the region (Su et al., 2016). 


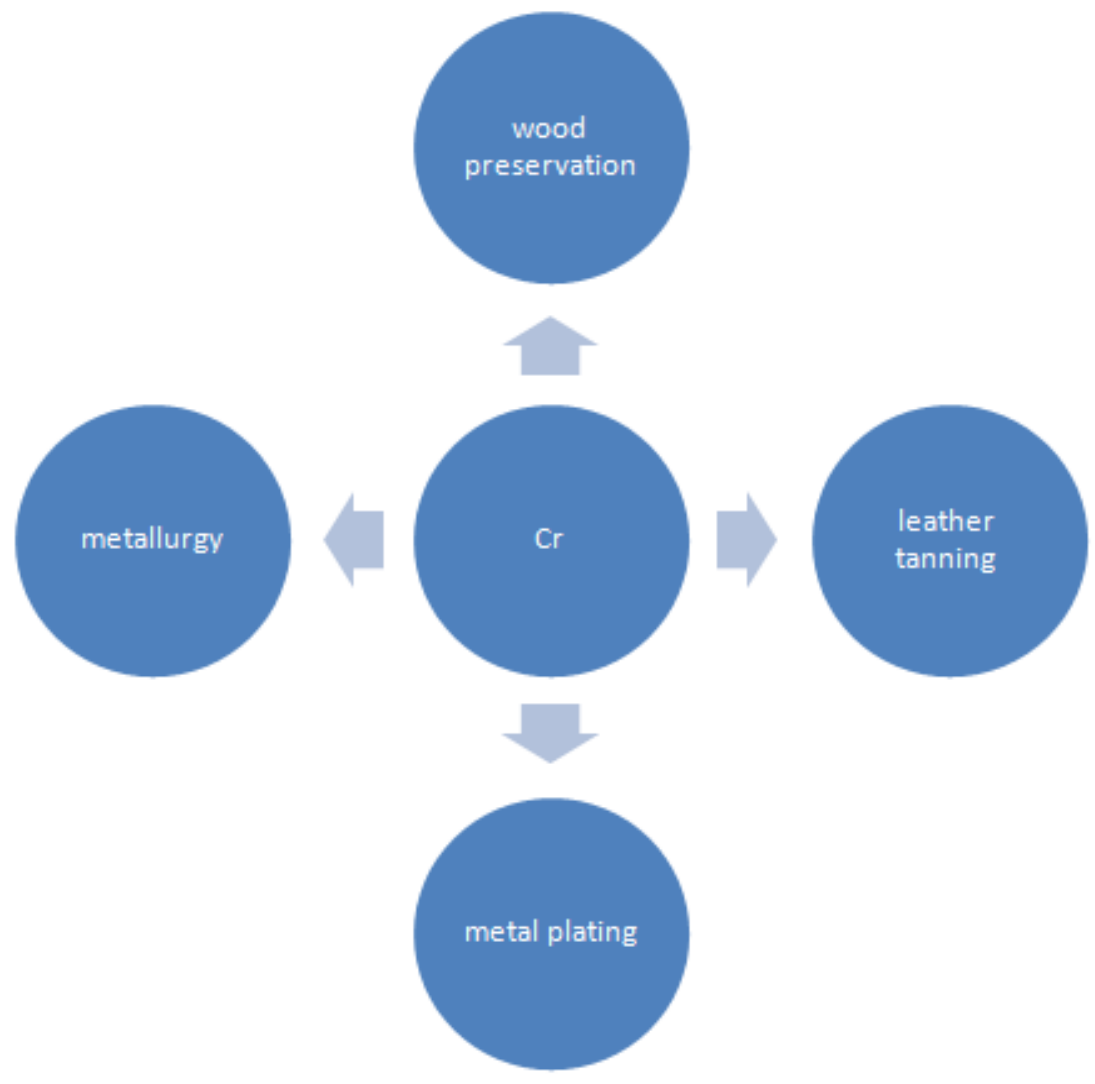

Fig 4: Some sources of chromium in the environment

\section{IRON BASED TECHNOLOGIES FOR METAL IMMOBILIZATION}

Compared with other soil amendments such as aluminum and manganese oxides and kaolinite, iron-based amendments such as zerovalent iron powder, ferrihydrite and ferric chloride were the most effective at reducing As in leachates in a soil column leaching study (Doherty et al., 2017). In this study, zerovalent iron powder and ferrihydrite were the most effective for the reduction of As in leachate reducing As concentrations by more than 80\% (Doherty et al., 2017).

\subsection{Iron oxides}

Iron oxides occur naturally in the soil and are important scavengers for As and other metals and has been reported to immobilize As in short and long term experiments (Fresno et al., 2016). In a study, iron oxides with three different degrees of crystallization were used for the immobilization of $\mathrm{Cd}$ in contaminated sediments because well crystallized iron oxide have higher stabilities under reducing and acidic conditions (Yin et al., 2016; Li et al., 2019). Results of the study showed that crystalline iron oxides were able to reduce the mobile fraction and increase the stable fraction of $\mathrm{Cd}$ in contaminated sediment after treatment for 56 days ( $\mathrm{Li}$ et al., 2019). 
International Journal of Agriculture and Environmental Research

ISSN: 2455-6939

Volume: 06, Issue: 03 "May-June 2020"

Nano-sized particles of three iron oxides showed high capacity to remove $\mathrm{Cd}$ with adsorption capacities that ranged from 2.8 to $7.4 \mathrm{mg} \mathrm{Cd} / \mathrm{g}$ substrate via mechanisms such as ion exchange, hydrolysis, electrostatic attractions, chemical binding or specific interactions (Zhang et al., 2016).

The synthesis of iron oxides from plant leaf extracts is more environmentally friendly than traditional methods which involve toxic chemicals and solvents and result in detrimental residues when applied to soils (Wang et al., 2014). Weng et al. (2016) showed that iron oxide synthesized from eucalyptus leaf extracts effectively removed $\mathrm{Cu}$ from wastewater. Similarly, phytogenic iron oxide nanoparticles (PION) synthesized from leaf extracts of Excoecaria cochinchinensis effectively removed $\mathrm{Cd}$ from aqueous solution (Lin et al., 2018).

The application of phytogenic iron oxide nanoparticles synthesized from leaf extracts of Excoecaria cochinchinensis also effectively immobilized $\mathrm{Cd}$ under both oxic and anoxic conditions in the soil via mechanisms such as formation of insoluble hydroxides at elevated $\mathrm{pH}$; ligand complexation and co-precipitation (Lin et al., 2019). Green iron oxide nanoparticles synthesized from the leaf extracts of Euphorbia cochinchinensis decreased mobile As fractions after 120 days of incubation and transformed As to more stable fractions (Su et al., 2019).

\subsection{Zerovalent iron}

Zerovalent iron (ZVI) has been used for the in-situ immobilization of As in contaminated soils (Miretzky and Cirelli, 2010; Nielsen et al., 2011). Upon addition to the soil, zerovalent iron is rapidly transformed into reactive iron (hydro) oxides which can adsorb both cations and anions due to their high surface area and large number of reactive terminal adsorptive groups (Komarek et al., 2013). Application of zerovalent iron and compost to a copper contaminated soil increased the content of iron hydr(oxides) which also increased the copper binding to iron hydr(oxides) in treated soil (Kumpiene et al., 2011).

Another study investigated the long-term effect of zerovalent iron on dissolved copper and arsenic in contaminated soils and results showed that the ZVI remained reactive for 6 to 15 years after application while the dissolved concentrations of $\mathrm{Cu}$ and As decreased in the treated soil (Tiberg et al., 2016). At the end of the study, there was a shift in copper speciation from organic matter complexes in the untreated soil to surface complexes with iron (hydr)oxides in the ZVItreated soil (Tiberg et al., 2016). 


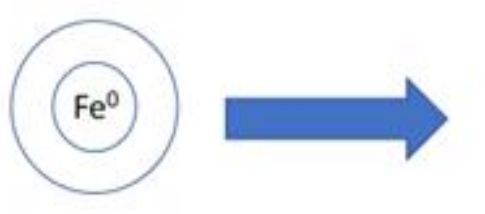

ZVI

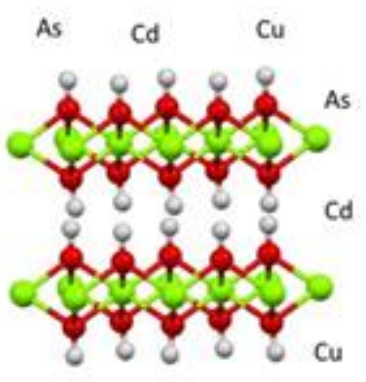

Iron (II) hydroxide

\section{Fig 5: Transformation of zerovalent iron (ZVI) in soil after application.}

The use of zerovalent $\mathrm{Fe}$ as a precursor of iron oxides has been shown to result in a decrease in As mobility and zero-valent iron nanoparticles (nZVI) have recently been used in metal immobilization due to their high surface area and high reactivity (Machado et al., 2013). Iron nanoparticles behave like reducing agents by donating their electrons to pollutants which are reduced as they accept the electrons thereby making pollutants more stable, less mobile and less toxic in the soil (Galdames et al., 2017). However, there is concern about the uncertainty of the long-term fate, transformation and ecotoxicity of nZVI in contaminated sites as they could potentially contaminate the food chain or spread other non-target pollutants in the soil (Masciangioli and Zhang, 2003).

The application of nZVI for in-situ immobilization of a soil contaminated with both As and $\mathrm{Cr}$ led to a decrease in the concentration of As in the soil and a decrease of concentration of $\mathrm{Cr}$ in leachates of tested soils (Galdames et al., 2017). The efficiency of nZVI and ngeothite to immobilize As in a polluted soil was tested in a recent study. At a dose of $2 \%$, nZVI reduced As in mobile fractions by about $89.5 \%$ while ngeothite reduced As concentrations by about $82.5 \%$ at the lowest dose of $0.2 \%$ (Baragano et al., 2020).

The efficiency of nZVI in remediation of contaminated soils is limited by the strong tendency of its particles to agglomerate (Zhang et al., 2011; Xie et al., 2016). In order to overcome this limitation and facilitate the delivery and mobility of nZVI in soils, nZVI is immobilized onto a carrier such as resin, potato starch, zeolite, or mesoporous silica (Qiu et al., 2011, Fu et al., 2013, Kim et al., 2013) or by increasing colloidal stability with the addition of other soil amendments (Dong and Lo, 2013).

Iron phosphate nanoparticles stabilized by sodium carboxymethyl cellulose and supported by biochar was used to immobilize $\mathrm{Cd}$ in contaminated soil in a past study (Qiao et al., 2017). The treatment decreased the mobility of $\mathrm{Cd}$ by about $81.3 \%$ after 28 days and reduced the bioaccessibility of $\mathrm{Cd}$ by about $80 \%$ (Qiao et al., 2017). In a recent study, synthetic iron sulfide 
International Journal of Agriculture and Environmental Research

ISSN: 2455-6939

Volume: 06, Issue: 03 "May-June 2020"

nanoparticles (FeS NPs) stabilized with carboxymethyl cellulose (CMC) were used to remediate $\mathrm{Cr}$ (VI) contaminated groundwater and saturated soil. The treatment reduced $\mathrm{Cr}$ (VI) concentrations in leachates from contaminated soil from $4.58 \mathrm{mg} \mathrm{L}^{-1}$ to $46.8-80.7 \mu \mathrm{g} \mathrm{L}^{-1}$ (Wang et al., 2019).

Biochar supported carboxymethyl cellulose (CMC)-stabilized nanoscale iron sulfide (FeS) composite was used for immobilization of chromium $\mathrm{Cr}(\mathrm{VI})$ in contaminated soil and results showed that the treatment reduced leachable $\mathrm{Cr}$ and extractable $\mathrm{Cr} 94.7 \%$ and $95.6 \%$ respectively (Lyu et al., 2018).

Microscale iron sulfide stabilized by CMC was used for the immobilization of $\mathrm{Cr}$ (VI) in contaminated soil. The treatment reduced $\mathrm{Cr}(\mathrm{VI})$ and decreased leachate concentrations in the Toxicity Characteristics Leaching Procedure (TCLP), decreased bioaccessibility of $\mathrm{Cr}$ and converted the exchangeable $\mathrm{Cr}$ fraction to the Fe-Mn oxides bound fraction ( $\mathrm{Li}$ et al., 2017). Compared with iron sulfate, stabilized microscale iron sulfide had a higher $\mathrm{Cr}$ removal and higher immobilization efficiency (Li et al., 2017).

Biochar supported zerovalent iron nanoparticles was used for the immobilization of $\mathrm{Cr}$ (VI) in chromium contaminated soil. Results showed an immobilization efficiency of $100 \%$ and 91.94 $\%$ for $\mathrm{Cr}(\mathrm{VI})$ and $\mathrm{Cr}$ total respectively with $\mathrm{Cr}$ almost completely converted to $\mathrm{Fe}-\mathrm{Mn}$ oxides and organic matter bound fractions (Su et al., 2016). Frick et al. (2019) showed that a combination of biochar and zerovalent iron effectively reduced water-extractable concentrations of $\mathrm{Cr}, \mathrm{Cu}$ and $\mathrm{As}$ in CCA contaminated soil and reduced the toxic effects on the soil microbial community in the soil.

\subsection{Iron salts}

Iron salts such as sulfates have been recommended for metal immobilization because they immobilize contaminants such as arsenic more efficiently than iron oxides by inducing chemical reactions such as precipitation (Komarek et al., 2013; Cutler et al., 2014). A recent study evaluated the effect of iron sulfate in combination with organic amendments such as paper mill sludge, olive mill waste compost and olive tree pruning biochar on the immobilization of As and $\mathrm{Cu}$ in contaminated soils. They reported that iron sulfate with compost was the most suitable treatment that reduced both $\mathrm{As}$ and $\mathrm{Cu}$ availability and enhanced plant growth (Fresno et al., 2016). However, another iron salt was reported to be more effective than iron sulfate on a microscale.

Another iron salt, iron hydroxyl phosphate was used in the simultaneous immobilization of $\mathrm{Cd}$, As and $\mathrm{Pb}$ in contaminated soil (Yuan et al., 2017). Application of iron hydroxyl phosphate resulted in an increase of $\mathrm{Cd}, \mathrm{As}$ and $\mathrm{Pb}$ in residual fractions and a decrease in exchangeable 
International Journal of Agriculture and Environmental Research

ISSN: $2455-6939$

Volume: 06, Issue: 03 "May-June 2020"

fractions as shown by sequential extractions (Yuan et al., 2017). This shows a decrease in mobility and bioavailability of these toxic elements in the soil after application of iron hydroxyl phosphate. Fe (II) and Al (III) layered double hydroxide completely immobilized Cr (VI) in contaminated soil probably via adsorption and reduction (He et al., 2018).

\subsection{Iron-rich Industrial By Products}

Some iron-rich industrial by-products such as red mud, iron oxide coated cement, water treatment sludges, and steel shot have been used for the immobilization of metals in contaminated soils because of their cost effectiveness and potential to reduce mobility of metals and metalloids (Rodriguez-Jorda et al., 2010). Red mud and aluminum rich water treatment residue were used for the immobilization of As and $\mathrm{Cu}$ under two different redox conditions. Both amendments reduced plant uptake of As and $\mathrm{Cu}$ under aerobic conditions even though the efficiency of the treatments was influenced by soil conditions and source of contamination (Silvetti et al., 2014).

Soil amendments such as red mud, limestone and furnace slag were added individually and in two amendment combinations to mining soil contaminated with $\mathrm{As}, \mathrm{Cd}, \mathrm{Pb}$, and $\mathrm{Zn}$. A combination of red mud and limestone was the most effective at reducing extractable As and heavy metal concentrations while $2 \%$ red mud was most effective at reducing exchangeable fractions and decreasing labile metal fractions (Lee et al., 2011).

Red gypsum, an industrial by product from the production of titanium dioxide was tested as one of the amendments in a study on the immobilization of arsenic in contaminated soil. Red gypsum was one of the amendments that was effective in reducing the extractability of arsenic and considerably large amounts of arsenic was associated with the iron mineral (maghemite) in the red gypsum (Rodriguez-Jorda et al., 2010).

A by-product of titanium dioxide containing ferrous sulfate and phosphates was used to prepare polyhydric hydroxyl ferric phosphate (PHFP) which was then used for the immobilization of Cd in the soil. PHFP removed $33 \%$ extractable $\mathrm{Cd}$ and reduced water-soluble Cd concentrations by $56 \%$ (Yuan et al., 2017). A metal sorbent, FIXALL, consisting mainly of ferrihydrite and gypsum was synthesized from ferrous sulfate, a by product of titanium ore refinement and used for the simultaneous removal of $\mathrm{As}$ and $\mathrm{Pb}$ from soil and solution (Kameda et al., 2017). FIXALL decreased the concentration of water-soluble $\mathrm{As}$ and $\mathrm{Pb}$ simultaneously and continuously for 754 days (Kameda et al., 2017). The mechanism for As removal was by surface adsorption on ferrihydrite (Kameda et al., 2017). Ferrihydrite was the most effective amendment in reducing As bioavailability when the following amendments were added to arsenic contaminated soil; sepiolite, red mud, iron grit, phosphogypsum, ferrihydrite, iron phosphate, and layered double oxides (LDO) (Sun et al., 2015). 
International Journal of Agriculture and Environmental Research

ISSN: 2455-6939

Volume: 06, Issue: 03 "May-June 2020"

Industrial by-products from steel making processes (slag materials) removed As from leachates from an abandoned mine via adsorption of arsenate ions on the active sites of the $\mathrm{Fe}$ and $\mathrm{Al}$ oxides and hydroxides of the by-products (Ayala and Fernandez, 2020). The by-products were effective in simultaneously removing pollutants such as $\mathrm{As}, \mathrm{Hg}, \mathrm{Pb}, \mathrm{Cu}, \mathrm{Ni}, \mathrm{Zn}$, and $\mathrm{Cd}$ (Ayala and Fernandez, 2020). Steel abrasive and oxygen scarfing granulate, two iron rich industrial by products decreased arsenic concentration in pore water of CCA contaminated soils but their effectiveness reduced with increasing organic matter content (Lidelow et al., 2007).

Addition of $\mathrm{Fe}-\mathrm{Mn}$ wastes produced by the water treatment plant in increasing doses substantially reduced As extractability in highly contaminated soils (Lewinska et al., 2018). In another study with Fe-Mn binary oxide wastes from water treatment plants, arsenite (As III) was oxidized to arsenate (As V) by the Mn oxide component while the arsenate is sorbed to the $\mathrm{Fe}$ oxide (McCann et al., 2018). The bioaccessibility of arsenic was significantly reduced by the binary waste addition (McCann et al., 2018).

\section{FUTURE DIRECTIONS}

Review of current literature showed that a lot of work has been done on iron-based technologies in remediation of aqueous solutions but there is paucity of published data on the use of these materials for the remediation of $\mathrm{As}, \mathrm{Cu}$ and $\mathrm{Cd}$ in contaminated soils. There was however a lot more work done on $\mathrm{Cr}$ immobilization using iron-based materials in the soil especially zerovalent iron nanoparticles in chromium contaminated soils. The use of plant extracts to synthesize iron oxides nanoparticles is fast gaining attention but similar studies should be conducted with zerovalent iron nanoparticles. There have been studies using green synthesized zerovalent iron nanoparticles to remediate soils polluted with organic substances such as ibuprofen but very few or no studies with metal contaminated soils.

\section{CONCLUSION}

Iron based technologies have been shown to be efficient in the immobilization of $\mathrm{As}, \mathrm{Cu}, \mathrm{Cr}$ and Cd contaminated soils. A higher percentage of studies on iron-based immobilization are on nanoscale iron rich materials such as zerovalent iron or iron oxide nanoparticles. However, there is concern about the impact of nanomaterials on the environment as they could potentially contaminate the food chain or spread other non-target pollutants in the soil. Some studies have shown that this is not always the case. The use of phytogenic or green iron oxide nanoparticles synthesized from leaf extracts is a more environmentally friendly alternative in the use of these iron-based technologies. A lot of work has been done with iron rich industrial by products because they are cheap and readily available amendments that have been proved effective in metal contaminated soils. 
International Journal of Agriculture and Environmental Research

ISSN: 2455-6939

Volume: 06, Issue: 03 "May-June 2020"

\section{REFERENCES}

Andreazza, R., Pieniz, S., Wolf, L., Lee, M., Camargo, F., and Okeke, B. (2010) Characterization of copper bioreduction and biosorption by a highly copper resistant bacterium isolated from copper-contaminated vineyard soil. Science of the Total Environment 408, 1501-1507

Ayala, J., \& Fernández, B. (2020). Industrial waste materials as adsorbents for the removal of As and other toxic elements from an abandoned mine spoil heap leachate: a case study in Asturias, Journal of Hazardous Materials, 384, 121446, https://doi.org/10.1016/j.jhazmat.2019.121446.

Baragaño, D., Alonso, J., Gallego, J.R., Lobo, M.C., \& Gil-Díaz, M. (2020) Zero valent iron and goethite nanoparticles as new promising remediation techniques for As-polluted soils, Chemosphere, 238, 124624, https://doi.org/10.1016/j.chemosphere.2019.124624.

Bjelková, M., Genčurová, V., \& Griga, M. (2011) Accumulation of cadmium by flax and linseed cultivars in field-simulated conditions: A potential for phytoremediation of $\mathrm{Cd}$ contaminated soils, Industrial Crops and Products, 33, (3), 761-774, https://doi.org/10.1016/j.indcrop.2011.01.020.

Borah, P., Singh, P., Rangan, L., Karak, T., \& Mitra, S. (2018) Mobility, bioavailability and ecological risk assessment of cadmium and chromium in soils contaminated by paper mill wastes. Groundwater for Sustainable Development, 6, 189-199, https://doi.org/10.1016/j.gsd.2018.01.002.

Cai, Y., Cabrera, J.C., Geogiardis, M., \& Jayachandran, K. (2002) Assessment of arsenic mobility in the soils of some golf courses in South Florida. Science of Total Environment 291, 123-134.

Cornu, J.Y., Huguenot, D., Jezequel, K., Lollier, M., \& Lebeau, T. (2017). Bioremediation of copper-contaminated soils by bacteria. World Journal of Microbiology and Biotechnology 33, 26.

Cui, H., Fan, Y., Fang, G., Zhang, H., Su, B., \& Zhou, J. (2016). Leachability, availability and bioaccessibility of $\mathrm{Cu}$ and $\mathrm{Cd}$ in a contaminated soil treated with apatite, lime and charcoal: A five-year field experiment. Ecotoxicology and Environmental Safety 134P1, $148-155$.

Cutler, W.G., El-Kadi, A., Hue, N.V., Peard, J., Scheckel, K., \& Ray, C. (2014). Iron amendments to reduce bioaccessible arsenic. Journal of Hazardous Materials 279, 554561. http://dx.doi.org/10.1016/j.jhazmat.2014.07.043. 
International Journal of Agriculture and Environmental Research

ISSN: 2455-6939

Volume: 06, Issue: 03 "May-June 2020"

Doherty, S.J., Tighe, M.K., \& Wilson, S.C. (2017) Evaluation of amendments to reduce arsenic and antimony leaching from co-contaminated soils, Chemosphere, 174, 208-217. https://doi.org/10.1016/j.chemosphere.2017.01.100.

Dong, H., Deng, J., Xie, Y., Zhang, C., Jiang, Z., Cheng, Y., Hou, K., \& Zeng, G. (2017) Stabilisation of nanoscale zero-valent iron (nZVI) with modified biochar for $\mathrm{Cr}$ (VI) removal from aqueous solution. Journal of Hazardous Materials 322, 79-86. https://doi.org/10.1016/j.jhazmat.2017.03.002.

Dong, H., \& Lo, I.M. (2013). Influence of humic acid on the colloidal stability of surface modified nano zero-valent iron. Water Research 47, 419-427.

EPA (1996). Recent developments for in situ treatment of metal contaminated soils. Prepared for: U.S. Environmental Protection Agency, Office of solid waste and emergency response. Technology Innovation Office, Washington, DC.

EPA (2018). What is Superfund? https://www.epa.gov/superfund/what-superfund Accessed December 12, 2019.

Fillol, C., Dor, F., Clozel, B., Goria, S., \& Seta, N. (2010) Does arsenic in soil contribute to arsenic urinary concentrations in a French population living in a naturally arsenic contaminated area?, Science of The Total Environment, 408, (23), 6011-6016, https://doi.org/10.1016/j.scitotenv.2010.08.039.

Fresno, T., Moreno-Jiménez, E.\& Peñalosa, J.M. (2016) Assessing the combination of iron sulfate and organic materials as amendment for an arsenic and copper contaminated soil. A chemical and ecotoxicological approach, Chemosphere, 165, 539-546, https://doi.org/10.1016/j.chemosphere.2016.09.039.

Frick, H., Tardif, S., Kandeler, E., Holm, P.E., \& Brandt, K.K. (2019) Assessment of biochar and zero-valent iron for in-situ remediation of chromated copper arsenate contaminated soil, Science of The Total Environment 655, 414-422, https://doi.org/10.1016/j.scitotenv.2018.11.193.

Fu, F.L., Ma, J., Xie, L.P., Tang, B., Han, W.J., \& Lin, S.Y. (2013). Chromium removal using resin supported nanoscale zero-valent iron. Journal of Environmental Management 128, $822-827$.

Galdames, A., Mendoza, A., Orueta, M., de Soto García, I.S., Sánchez, M., Virto, I., \& Vilas, J.L. (2017). Development of new remediation technologies for contaminated soils based on the application of zero-valent iron nanoparticles and bioremediation with compost. Resource-Efficient Technologies 3, 166-176 
International Journal of Agriculture and Environmental Research

ISSN: 2455-6939

Volume: 06, Issue: 03 "May-June 2020"

Garcia-Manyes, S., Jimenez, G., Padro, A., Rubio, R., \& Rauret, G. (2002). Arsenic speciation in contaminated soils. Talanta 58, 97-109

Garrido, T., Mendoza, J., \& Arriagada, F. (2012) Changes in the sorption, desorption, distribution, and availability of copper, induced by application of sewage sludge on Chilean soils contaminated by mine tailings. Journal of Environmental Sciences 24(5), 912-918

Giacomino, A., Malandrino, M., Abollino, O., Velayutham, M., Chinnathangavel, T., \& Mentasti, E. (2010). An approach for arsenic in a contaminated soil: Speciation, fractionation, extraction and effluent decontamination. Environmental Pollution 158, $416-423$

Ginocchio, R. (2000). Effects of a copper smelter on a grassland community in the Puchuncavi valley, Chile. Chemosphere 41 (1-2), 15-23.

Ginocchio, R., Carvallo, G., Toro, I., Bustamante, E., Silva, Y., \& Sepulveda, N. (2004). Microspatial variation of soil metal pollution and plant recruitment near a copper smelter in central Chile. Environmental Pollution 127 (3), 343-352.

Ginocchio, R., Sanchez P., de la Fuente, L., Camus, I., Bustamante, E., Silva, Y., Urrestarazu, P., Torres, J., \& Rodríguez, P. (2006). Agricultural soils spiked with copper mine wastes and copper concentrate: implications for copper bioavailability and bioaccumulation. Environmental Toxicology and Chemistry 25 (3), 712-718.

Girotto, E., Ceretta, C., Rossato, L., Farias, J., Brunetto, G., Miotto, A., Tiecher, T., de Conti, L., Lourenzi, C., Schmatz, R., Giachini, A., \& Nicoloso, F. (2016) Biochemical changes in black oat (avena strigosa schreb) cultivated in vineyard soils contaminated with copper. Plant Physiology and Biochemistry 103, 199-207, https://doi.org/10.1016/j.plaphy.2016.02.030.

Gonzaga, M. I., de Almeida Silva Matias, M. I., Andrade, K.R., de Jesus, A.N., da Costa Cunha, G., de Andrade, R.S., \& de Jesus Santos, J.C. (2020) Aged biochar changed copper availability and distribution among soil fractions and influenced corn seed germination in a copper-contaminated soil, Chemosphere, 240, 124828, https://doi.org/10.1016/j.chemosphere.2019.124828.

Guan, X., Yang, H., Sun, Y., \& Qiao, J. (2019) Enhanced immobilization of chromium (VI) in soil using sulfidated zero-valent iron. Chemosphere 228, 370-376 
International Journal of Agriculture and Environmental Research

ISSN: 2455-6939

Volume: 06, Issue: 03 "May-June 2020"

He, X., Zhong, P., \& Qiu, X. (2018) Remediation of hexavalent chromium in contaminated soil by $\mathrm{Fe}(\mathrm{II})$-Al layered double hydroxide, Chemosphere 210, 1157-1166, https://doi.org/10.1016/j.chemosphere.2018.07.048.

Hooda, P.S. (2010). Trace Elements in Soils. John Wiley and Sons, Ltd., Chichester, West Sussex, U.K..

Hou, S., Wu, B., Peng, D., Wang, Z., Wang, Y., \& Xu, H. (2019) Remediation performance and mechanism of hexavalent chromium in alkaline soil using multi-layer loaded nano-zerovalent iron. Environmental Pollution 252, 553-561 https://doi.org/10.1016/j.envpol.2019.05.083.

Inkham, R., Kijjanapanich, V., Huttagosol, P., \& Kijjanapanich, P. (2019). Low-cost alkaline substances for the chemical stabilization of cadmium-contaminated soils, Journal of Environmental Management, 250, 109395, https://doi.org/10.1016/j.jenvman.2019.109395.

Kabata-Pendias, A. (2001) Trace elements in Soils and plants, 3rd edn. CRC Press, Boca Raton

Kabata-Pendias, A., \& Mukherjee, A.B. (2007). Trace Elements From Soil To Human. SpringerVerlag, Berlin, Heidelberg, Germany.

Kameda, K., Hashimoto, Y., Wang, S., Hirai, Y., \& Miyahara, H. (2017). Simultaneous and continuous stabilization of $\mathrm{As}$ and $\mathrm{Pb}$ in contaminated solution and soil by a ferrihydritegypsum sorbent, Journal of Hazardous Materials, 327, 171-179, https://doi.org/10.1016/j.jhazmat.2016.12.039.

Khan, M.A., Khan, S., Khan, A., Alam, M. (2017). Soil contamination with cadmium, consequences and remediation using organic amendments. Science of Total Environment 601-602, 1591-1605. https://doi.org/10.1016/j.scitotenv.2017.06.030.

Kim, E.J., \& Batchelor, B. (2009). Macroscopic and X-ray photoelectron spectroscopic investigation of interactions of arsenic with synthesized pyrite. Environmental Science and Technology 43, 2899-2904

Kim, S.A., Kannan, S.K., Lee, K.J., Park, Y.J., Shea, P.J., Lee, W.H., Kim, H.J., \& Oh, B.T. (2013). Removal of $\mathrm{Pb}(\mathrm{II})$ from aqueous solution by a zeolite nanoscale zerovalent iron composite. Chemical Engineering Journal 217, 54-60.

Kim, E.J., Yoo, J., \& Baek, K. (2014). Arsenic speciation and bioaccessibility in arseniccontaminated soils: Sequential extraction and mineralogical investigation, Environmental Pollution. 186, 29-35 https://doi.org/10.1016/j.envpol.2013.11.032. 
International Journal of Agriculture and Environmental Research

ISSN: 2455-6939

Volume: 06, Issue: 03 "May-June 2020"

Komarek, M., Vanek, A., \& Ettler, V. (2013). Chemical stabilization of metals and arsenic in contaminated soils using oxides. A review. Environmental Pollution 172, 9-22. http://dx.doi.org/10.1016/j.envpol.2012.07.045.

Kubier, A., Wilkin, R.T., \& Pichler, T. (2019). Cadmium in soils and groundwater: A review, Applied Geochemistry, 108, 104388, https://doi.org/10.1016/j.apgeochem.2019.104388.

Kumpiene, J., Mench, M., Bes, C.M., \& Fitts, J.P. (2011). Assessment of aided phytostabilization of copper-contaminated soil by X-ray absorption spectroscopy and chemical extractions. Environmental Pollution 159, 1536-1542.

Lee, S., Kim, E.Y., Park, H., Yun, J., \& Kim, J. (2011). In situ stabilization of arsenic and metalcontaminated agricultural soil using industrial by-products, Geoderma, 161, (1-2), 1-7. https://doi.org/10.1016/j.geoderma.2010.11.008.

Lewińska, K., Karczewska, A., Siepak, M., \& Gałka, B. (2018). Potential of Fe-Mn wastes produced by a water treatment plant for arsenic immobilization in contaminated soils, Journal of Geochemical Exploration, 184, 226-231, https://doi.org/10.1016/j.gexplo.2016.12.016.

Li, Y., Wang, W., Zhou, L., Liu, Y., Mirza, Z., \& Lin, X. (2017). Remediation of hexavalent chromium spiked soil by using synthesized iron sulfide particles, Chemosphere, 169, 131-138. https://doi.org/10.1016/j.chemosphere.2016.11.060.

Li, X., Yang, Z., Zhang, C., Wei, J., Zhang, H., Li, Z., Ma, C., Wang, M., Chen, J., \& Hu, J. (2019) Effects of different crystalline iron oxides on immobilization and bioavailability of Cd in contaminated sediment. Chemical Engineering Journal 373, 307-317

Lidelöw, S., Ragnvaldsson, D., Leffler, P., Tesfalidet, S., \& Maurice, C. (2007). Field trials to assess the use of iron-bearing industrial by-products for stabilisation of chromated copper arsenate-contaminated soil. Science of the Total Environment 387, 68-78

Lin, J., Su, B., Sun, M., \& Chen, Z. (2018) Biosynthesized iron oxide nanoparticles used for optimized removal of cadmium with response surface methodology. Science of Total Environment 627, 314-321.

Lin, J., Sun, M., Su, B., Owens, G., \& Chen, Z. (2019) Immobilization of cadmium in polluted soils by phytogenic iron oxide nanoparticles. Science of the Total Environment 659, 491498

Lyu, H., Zhao, H., Tang, J., Gong, Y., Huang, Y., Wu, Q., \& Gao, B. (2018). Immobilization of hexavalent chromium in contaminated soils using biochar supported nanoscale iron 
International Journal of Agriculture and Environmental Research

ISSN: 2455-6939

Volume: 06, Issue: 03 "May-June 2020"

sulfide composite, $\quad$ Chemosphere, 360-369, https://doi.org/10.1016/j.chemosphere.2017.11.182.

Machado, S., Stawiński, W., Slonina, P., Pinto, A.R., Grosso, J.P., Nouws, H.P., Albergaria, J.T., \& Delerue-Matos, C. (2013). Application of green zero-valent iron nanoparticles to the remediation of soils contaminated with ibuprofen, Science of The Total Environment, 461-462, 323-329, https://doi.org/10.1016/j.scitotenv.2013.05.016.

Marescotti, P., Carbone, C., De Capitani, L., Grieco, G., Lucchetti, G., \& Servida, D. (2008). Mineralogical and geochemical characterisation of open-air tailing and waste rock dumps from the Libiola $\mathrm{Fe}-\mathrm{Cu}$ sulphide mine (Eastern Liguria, Italy). Environmental Geology $53,1613-1626$.

Marescotti, P., Azzali, E., Servida, D., Carbone, C., Grieco, G., De Capitani, L., \& Lucchetti, G. (2010). Mineralogical and geochemical spatial analyses of a waste-rock dump at the Libiola $\mathrm{Fe}-\mathrm{Cu}$ sulphide mine (Eastern Liguria, Italy). Environmental Earth Science 61, 187-199.

Marescotti, P., Roccotiello, E., Zotti, M., De Capitani, L., Carbone, C., Azzali, E., Mariotti, M.G., \& Lucchetti, G. (2013). Influence of soil mineralogy and chemistry on fungi and plants in a waste-rock dump from the Libiola mine (eastern Liguria, Italy). Per. Mineral. $82,141-162$.

Marković, J., Jović, M., Smičiklas, I., Šljivić-Ivanović, M., Onjia, A., Trivunac, K., \& Popović, A. (2019). Cadmium retention and distribution in contaminated soil: Effects and interactions of soil properties, contamination level, aging time and in situ immobilization agents. Ecotoxicology and Environmental Safety 174, 305-314, https://doi.org/10.1016/j.ecoenv.2019.03.001.

Masciangioli, T., \& Zhang, W.X. (2003) Environmental technologies at the nanoscale, Environmental Science and Technology 37 (5), 102A-108A.

McCann, C.M., Peacock, C.L., Hudson-Edwards, K.A., Shrimpton, T., Gray, N.D., \& Johnson, K.L. (2018). In situ arsenic oxidation and sorption by a Fe-Mn binary oxide waste in soil, Journal of Hazardous Materials, 342, 724-731, https://doi.org/10.1016/j.jhazmat.2017.08.066.

Meier, S., Curaqueo, G., Khan, N., Bolan, N., Rilling, J., \& Vidal, C. (2017). Effect of biochar on $\mathrm{Cu}$ immobilization and soil microbial communities in a metal-contaminated soil. Journal of Soils and Sediments 17, 1237-1250. 
International Journal of Agriculture and Environmental Research

ISSN: 2455-6939

Volume: 06, Issue: 03 "May-June 2020"

Miretzky, P., \& Cirelli, A.F. (2010). Remediation of arsenic-contaminated soils by iron amendments: A review. Critical Reviews in Environmental Science and Technology 40, 93-115.

Mitzia, A., Vítková, M., \& Komárek, M. (2020) Assessment of biochar and/or nano zero-valent iron for the stabilisation of $\mathrm{Zn}, \mathrm{Pb}$ and $\mathrm{Cd}$ : A temporal study of solid phase geochemistry under changing soil conditions, Chemosphere 242, 125248, https://doi.org/10.1016/j.chemosphere.2019.125248.

Namiesnik, J., \& Rabajczyk, A. (2012). Speciation analysis of chromium in environmental samples. Critical Reviews in Environmental Science and Technolology 42, 327-377. https://doi.org/10.1080/10643389.2010.518517.

National Toxicology Program (2000). Ninth Report on Carcinogens. National Toxicology Program, Research Triangle Park, NC, USA.

Neaman, A., Reyes, L., Trolard, F., Bourrié, G., \& Sauvé, S. (2009) Copper mobility in contaminated soils of the Puchuncaví valley, central Chile. Geoderma 150, 359-366

Nejad, Z. D., Jung, M. C., \& Kim, K. H. (2018). Remediation of soils contaminated with heavy metals with an emphasis on immobilization technology. Environmental Geochemistry and Health 40, 927-953.

Newton, K., Amarasiriwardena, D., \& Xing, B. (2006) Distribution of soil arsenic species, lead and arsenic bound to humic acid molar mass fractions in a contaminated apple orchard. Environmental Pollution 143, 197-205

Nielsen, S.S., Petersen, L.R., Kjeldsen, P., \& Jakobsen, R. (2011). Amendment of arsenic and chromium polluted soil from wood preservation by iron residues from water treatment. Chemosphere 84, 383-389. https://doi.org/10.1016/j.chemosphere.2011.03.069.

$\mathrm{NIH}$ (2018). What are the Superfund site "NPL" statuses? https://toxmap.nlm.nih.gov/toxmap/faq/2009/08/what-are-the-superfund-site-nplstatuses.html Accessed December 12, 2019.

Palanivel, T.M., Sivakumar, N., Al-Ansari, A., \& Victor, R. (2020) Bioremediation of copper by active cells of Pseudomonas stutzeri LA3 isolated from an abandoned copper mine soil, Journal of Environmental Management, 253, 109706, https://doi.org/10.1016/j.jenvman.2019.109706.

Peters, R., McCurdy, R.F., \& Hindmarsh, J.T. (1996) Environmental aspects of arsenic toxicity. Critical Review of Clinical Laboratory Sciences 33 457-493. 
International Journal of Agriculture and Environmental Research

ISSN: 2455-6939

Volume: 06, Issue: 03 "May-June 2020"

Qiao, Y., Wu, J., Xu, Y., Fang, Z., Zheng, L., Cheng, W., Tsang, E., Fang, J., \& Zhao, D. (2017). Remediation of cadmium in soil by biochar-supported iron phosphate nanoparticles, Ecological Engineering, 106, Part A, 515-522, https://doi.org/10.1016/j.ecoleng.2017.06.023.

Qiu, X.H., Fang, Z.Q., Liang, B., Gu, F.L., \& Xu, Z.C. (2011). Degradation of decabromodiphenyl ether by nano zero-valent iron immobilized in mesoporous silica microspheres. Journal of Hazardous Materials 193, 70-81.

Rahman, M.S., Clark, M.W., \& Yee, L.H. (2019) Arsenic(V) sorption kinetics in long-term arsenic pesticide contaminated soils, Applied Geochemistry, 111, 104444, https://doi.org/10.1016/j.apgeochem.2019.104444.

Rodríguez-Jordá, M.P., Garrido, F., \& García-González, M.T. (2010). Assessment of the use of industrial by-products for induced reduction of As, and Se potential leachability in an acid soil. Journal of Hazardous Materials 175, 328-335.

Saha, B., \& Orvig, C. (2010). Biosorbents for hexavalent chromium elimination from industrial and municipal effluents. Coord. Chem. Rev. 254, 2959-2972.

Sauvé, S., Hendershot, W., \& Allen, H. (2000). Solid-solution partitioning of metals in contaminated soils: dependence on $\mathrm{pH}$ and total metal burden. Environmental Science \& Technology 34, 1125-1131.

Shutcha, M.N., Faucon, M.P., Kissi, C.K., Colinet, G., Mahy, G., Luhembwe, M.N., Visser, M., \& Meerts, P. (2015) Three years of phytostabilisation experiment of bare acidic soil extremely contaminated by copper smelting using plant biodiversity of metal-rich soils in tropical Africa (Katanga, DR Congo). Ecological Engineering 82, 81-90

Silvetti, M., Castaldi, P., Holm, P., Deiana, S., \& Lombi, E. (2014). Leachability, bioaccessibility and plant availability of trace elements in contaminated soils treated with industrial by-products and subjected to oxidative/reductive conditions, Geoderma, 214215, 204-212, https://doi.org/10.1016/j.geoderma.2013.09.010.

Simmons, R.W., Sukreeyapongse, O., Noble, A.D., \& Chinabut, N. (2005). Report of LDDIWMI Land Zoning and Cd Risk Assessment Activities Undertaken in Phatat Pha Daeng and Mae Tao Mai Sub-districts, Mae Sot, Tak Province, Thailand. International Water Management Institute (IWMI) and Land Development Department of Thailand, Bangkok, Thailand. 
International Journal of Agriculture and Environmental Research

ISSN: 2455-6939

Volume: 06, Issue: 03 "May-June 2020"

Stefaniuk, M., Oleszczuk, P., \& Sik Ok, Y. (2016) Review on nano zerovalent iron (nZVI): From synthesis to environmental applications, Chemical Engineering Journal 287, 618632 https://doi.org/10.1016/j.cej.2015.11.046.

Su, H.J., Fang, Z.Q., Tsang, P.E., Zheng, L., Cheng, W., Fang, J.Z., \& Zhao, D.Y. (2016). Remediation of hexavalent chromium contaminated soil by biochar-supported zero-valent iron nanoparticles. Journal of Hazardous Materials 318, 533-540.

Su, B., Lin, J., Owens, G., \& Chen, Z. (2019) Impact of green synthesized iron oxide nanoparticles on the distribution and transformation of As species in contaminated soil, Environmental Pollution https://doi.org/10.1016/j.envpol.2019.113668

Sun, Y., Sun, G., Xu, Y., Wang, L., Lin, D., Liang, X., \& Shi, X. (2012) In situ stabilization remediation of cadmium contaminated soils of wastewater irrigation region using sepiolite Journal of Environmental Sciences, 24(10) 1799-1805

Sun, Y., Liu, R., Zeng, X., Lin, Q., Bai, L., Li, L., Su, S., \& Wang, Y. (2015) Reduction of arsenic bioavailability by amending seven inorganic materials in arsenic contaminated soil. Journal of Integrative Agriculture, 14(7): 1414-1422

Tiberg, C., Kumpiene, J., Gustafsson, J., Marsz, A., Persson, I., Mench, M., \& Kleja, D.B. (2016). Immobilization of $\mathrm{Cu}$ and $\mathrm{As}$ in two contaminated soils with zero-valent iron Long-term performance and mechanisms, Applied Geochemistry, 67, 144-152 https://doi.org/10.1016/j.apgeochem.2016.02.009

Trakal, L., Vítkov, M., Hudcov, B., Beesley, L., \& Komarek, M. (2019) Biochar and its composites for metal(loid) removal from aqueous solutions. In: Ok, Y.S., Tsang, D.C.W., Bolan, N., Novak, J.M. (Eds.), Biochar from Biomass and Waste. Elsevier, Netherlands, pp. 113-141. https://doi.org/10.1016/B978-0-12-811729-3.00007-8.

Wang, Y., Fang, Z., Liang, B., \& Tsang, E.P. (2014) Remediation of hexavalent chromium contaminated soil by stabilized nanoscale zero-valent iron prepared from steel pickling waste liquor, Chemical Engineering Journal 247, 283-290, https://doi.org/10.1016/j.cej.2014.03.011.

Wang, T., Liu, Y., Wang, J., Wang, X., Liu, B., Wang, Y. (2019) In-situ remediation of hexavalent chromium contaminated groundwater and saturated soil using stabilized iron sulfide nanoparticles, Journal of Environmental Management, 231, 679-686, https://doi.org/10.1016/j.jenvman.2018.10.085. 
International Journal of Agriculture and Environmental Research

ISSN: 2455-6939

Volume: 06, Issue: 03 "May-June 2020"

Weng, X., Jin, X., Lin, J., Naidu, R., \& Chen, Z. (2016) Removal of mixed contaminants Cr(VI) and $\mathrm{Cu}(\mathrm{II})$ by green synthesized iron based nanoparticles. Ecological Engineering 97, 32-39.

Wu, H., Song, Z., Wang, X., Liu, Z., \& Tang, S. (2016) Increasing $\mathrm{CO}_{2}$ differentially affects essential and non-essential amino acid concentration of rice grains grown in cadmiumcontaminated Soils, Environmental Pollution, 216, 86-94, https://doi.org/10.1016/j.envpol.2016.05.049.

Xie, Y., Cheng, W., Tsang, P., \& Fang, Z. (2016). Remediation and phytotoxicity of decabromodiphenyl ether contaminated soil by zero valent iron nanoparticles immobilized in mesoporous silica microspheres, Journal of Environmental Management, 166, 478-483. https://doi.org/10.1016/j.jenvman.2015.10.042.

Yang, L., Liu, B., Lu, Y., Lu, F., Wu, X., You, W., \& Huang, B. (2020) Bioavailability of cadmium to celery (Apium graveolens L.) grown in acidic and Cd-contaminated greenhouse soil as affected by the application of hydroxyapatite with different particle sizes, Chemosphere, 240, 124916, https://doi.org/10.1016/j.chemosphere.2019.124916.

Yin, H., Tan, N., Liu, C., Wang, J., Liang, X., Qu, M., Feng, X., Qiu, G., Tan, W., \& Liu, F. (2016) The associations of heavy metals with crystalline iron oxides in the polluted soils around the mining areas in Guangdong Province, China, Chemosphere 161, 181-189.

Yuan, Y., Chai, L., Yang, Z., Wu, R., Liu, H., Liang, L., Shi, W. (2017). Immobilization of Cd and $\mathrm{Pb}$ in soils by polymeric hydroxyl ferric phosphate. Trans. Nonferrous Met. Soc. China 27, 1165-1171

Zhang, H.D., Huang, B., Dong, L.L., Hu, W.Y., Akhtar, M.S., \& Qu, M.K. (2017). Accumulation, sources and health risks of trace metals in elevated geochemical background soils used for greenhouse vegetable production in southwestern China. Ecotoxicology and Environmental Safety 137, 233-239.

Zhang, Y., Li, Y.M., \& Zheng, X.M. (2011). Removal of atrazine by nanoscale zero valent iron supported on organobentonite. Science of Total Environment 409, 625-630.

Zhang, C., Yu, Z., Zeng, G., Huang, B., Dong, H., Huang, J., Yang, Z., Wei, J., Hu, L., \& Zhang, Q. (2016) Phase transformation of crystalline iron oxides and their adsorption abilities for $\mathrm{Pb}$ and $\mathrm{Cd}$, Chemical Engineering Journal 284, 247-259.

Zhang, C., Yu, Z., Zeng, G., Jiang, M., Yang, Z., Cui, F., Zhu, M., Shen, L., \& Hu, L. (2014) Effects of sediment geochemical properties on heavy metal bioavailability. Environment International 73, 270-281. 
International Journal of Agriculture and Environmental Research

ISSN: 2455-6939

Volume: 06, Issue: 03 "May-June 2020"

Zotti, M., Di Piazza, S., Roccotiello, E., Lucchetti, G., Mariotti, M., Marescotti, P. (2014) Microfungi in highly copper-contaminated soils from an abandoned $\mathrm{Fe}-\mathrm{Cu}$ sulphide mine: Growth responses, tolerance and bioaccumulation, Chemosphere, 117, 471-476, https://doi.org/10.1016/j.chemosphere.2014.08.057. 